\title{
SEMINÁRIO JOÃO XXIII E CENTRO DE ESTUDOS MIGRATÓRIOS
}

\section{Memória de um passado recente}

\author{
Pe. Alfredo J. Gonçalves* \\ (Boxes: Dirceu Cutti **)
}

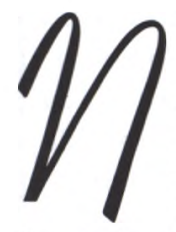

a trajetória do Seminário João XXIII, a sensibilidade sócio-pastoral para com os migrantes tem a idade do próprio edifício. Ele foi fundado ainda em 1954, passando a ter sua sede atual a partir de 1962 , quando foi inaugurado o prédio que abriga, atualmente, a casa formativa e o Instituto Teológico São Paulo (ITESP), localizado no Alto do Ipiranga da capital paulista. Em torno desta época, os seminaristas de filosofia e teologia que passaram por suas dependências, começaram a desenvolver uma ação pastoral em três frentes: presença na ex-favela do Vergueiro, localizada a cerca de dois quilômetros do seminário; algumas viagens às regiões onde a migração apresentava maiores desafios, tais como o nordeste brasileiro, Paraguai e o norte do Paraná; contatos com o Pe. Jacyr F. Braido e com Pe. Juarez Segalin, então à frente do Centro de Estudos Migratórios (CEM), fundado em 1969, e cujas dependências localizavam-se no prédio do Seminário. Neste contexto de crescente sensibilidade para o fenômeno das migrações, principalmente internas, é que surge o projeto do CEM, que pouco a pouco irá se consolidar na Província São Paulo, em conexão com projetos idênticos de abertura aos novos fenômenos migratórios, também atuantes nas demais províncias da Congregação dos Missionários de São Carlos. Em rápidas palavras, o CEM se enquadra no projeto da criação de centros que, de forma científica, pudessem acompanhar de perto o fenômeno das migrações em todos os países onde atuavam os padres escalabrinianos, constituindo mais tarde a Federação dos Centros de Estudos J. B. Scalabrini.

\section{FATOS E OPÇÕES}

\section{Operação periferia}

Nas três frentes assinaladas, cedo resultam iniciativas de maior fôlego e alcance. No caso da favela do Vergueiro, já em 1965 os clérigos começam uma presença incipiente, mas com certa freqüência. Depois, quando seus moradores foram despejados e parte deles transferidos para a região do Parque Santa Madalena, zona leste da cidade de São Paulo, os seminaristas os acompanham, iniciando assim uma atividade pastoral mais prolongada $\mathrm{e}$ sistemática nas comunidades de base da periferia. No decorrer dos anos, essa atividade pastoral expande-se para outras localidades, como o extremo sul do município, na área de Grajaú, e para a Baixada Santista, em Vicente de Carvalho, então Itapema. Tratava-se de regiões que enfrentavam o fenômeno da expansão das periferias urbanas, pela chegada de grandes levas de migrantes internos. $\mathrm{O}$ entusiasmo era tanto que, já em 1968, a pastoral dos seminaristas nos fins-de-semana praticamente deixa de ser "autorizada" para tornar-se "obrigatória", isto é, integrada à vida comunitária e estudantil.

A iniciativa de atuar nas comunidades em que residiam os migrantes coincide com uma inflexão pastoral que vinha sendo implementada pela Arquidiocese de São Paulo. De fato, no final dos anos 1960 e início da década de 1970, o próprio cardeal Dom Paulo Evaristo Arns, daria início à chamada "operação periferia”. Esta tinha um objetivo duplo de, por um lado, estender a presença da Igreja em direção aos extremos de uma cidade em acelerada e permanente expansão e, por outro, ampliar a construção de centros comunitários nas regiões mais afastadas e esquecidas do município. Inspirada pelo dinamismo do Concílio Vaticano II e de Medellín, era um apelo para que os institutos religiosos e membros do clero, que se concentravam nas regiões centrais da 
cidade de São Paulo, fossem ao encontro das populações pobres e migrantes que se instalavam nas margens da cidade, para que a Igreja se fizesse presente ali onde eles se encontravam. A estratégia, como era de esperar, representou um grande deslocamento centrífugo de sacerdotes, religiosos e religiosas do centro para a periferia.

\section{Viagem com os migrantes}

As viagens dos seminaristas aos pólos de origem das migrações começam em 1966, com uma primeira missão de férias ao norte do Paraná, estado para onde convergia um grande fluxo migratório atrás das plantações de café. Prosseguem em 1968 e 1969, respectivamente pela ferrovia Central do Brasil e pela Alta Sorocabana, nos caminhos trilhados pelas constantes levas de migrantes. Três preocupações de fundo estão na raiz de tais empreendimentos sócio-pastorais: primeiro, acompanhar de perto os migrantes desde a saída até o destino, experimentando as dificuldades do trânsito; segundo, contribuir para o estudo daquilo que viria a ser o CEM, através de incipientes pesquisas de campo; terceiro, engendrava-se aos poucos o projeto de construção de uma Casa de Acolhida ao Migrante na cidade de São Paulo. Paralelamente, um trabalho de acompanhamento aos migrantes era realizado junto à Hospedaria dos Migrantes no centro da cidade de São Paulo.

Um dos pioneiros das viagens e missões dos seminaristas foi o Alberto R.Zambiasi. Tendo vivenciado intensamente $\mathrm{o}$ trabalho de acompanhamento de famílias da favela do Vergueiro e as viagens para conhecer de perto a trajetória dos migrantes, ele tomou a iniciativa inusitada de interromper seus estudos de teologia, a fim de estudar sociologia e conhecer mais profundamente a realidade dos migrantes. Juntamente com um grupo de leigos animados pelo seu entusiasmo pelo carisma, fundou a Associação de Voluntários para a Integração dos Migrantes (AVIM), em novembro de 1974, tendo por finalidade ajudar os migrantes na sua integração na metrópole paulista. Inicialmente localizada no Ipiranga, veio a se instalar, posteriormente, nas dependências da Igreja Nossa Senhora da Paz, no bairro do Glicério. É fácil concluir que, a partir daí, a AVIM passaria a ser um ponto de referência para os migrantes internos recémchegados à cidade, e para a experiência pastoral dos seminaristas do João XXIII, bem como para a Igreja de São Paulo e as instituições governamentais. A AVIM iria, no início dos anos 1980, se consolidar como um Centro Pastoral de Acolhida, através da atividade de albergue para os migrantes na cidade de São Paulo.

O trabalho crescente nas comunidades da periferia de São Paulo, por uma parte, e as viagens pelos trilhos dos migrantes, por outra, desencadearam a necessidade de uma reflexão crítica que pudesse acompanhar esta nova prática pastoral. Assim, ainda em 1967, formandos e formadores do João XIII criaram a Equipe Missionária Scalabrini, que posteriormente viria a denominar-se Equipe Scalabriniana de Migrações (ESMI). A ESMI viria a tornar-se um espaço de encontro entre, de um lado, o intercâmbio das experiências cada vez mais numerosas e diferenciadas e, de outro, o aprofundamento teórico das mesmas, em confronto com os estudos de filosofia e teologia. Este espaço proporcionou uma reflexão que se entrelaçou de forma inextrincável com o desenvolvimento do CEM, que surgia naquele período, bem como com a ampliação e aprofundamento da atuação pastoral.

\section{Bastidores de uma decisão estratégica}

Um grupo de seminaristas do João XXIII, integrado por estudantes de filosofia e teologia, desde o ano de 1977 , vinha pleiteando a formação de pequenas comunidades inseridas no meio popular. Em outubro de 1978, pe. Jacyr Braido, diretor do CEM, foi atuar como assessor da CNBB, em Brasília, deixando vacante a sede do CEM.

Este fato redirecionou a postura do grupo. O que seria mais relevante no momento? Morar na periferia ou ocupar a direção do CEM? Como a $1^{\mathrm{a}}$ opção significava morar na periferia da região sul ou da leste, sinônimo de grande distância geográfica, em termos práticos uma opção vinha em prejuízo da outra. Foram várias reuniões, citese que as mesmas eram realizadas à noite, na praça da Rua Huet Bacelar, no Ipiranga. Morar na periferia era sinônimo de um testemunho de vida e estar à frente do CEM representava ocupar um espaço estratégico ímpar para os sonhos do grupo.

A decisão final recaiu por pleitear o espaço do CEM. A reivindicação para morar em pequenas comunidades foi deixada de lado e o grupo passou a ter uma nova postura - propositiva. Foram escolhidos dois nomes e apresentados à Direção Provincial (Luiz Bassegio e Dirceu Cutti, que cursavam o $3^{\circ}$ e o $2^{\circ}$ ano de teologia, respectivamente). Aduziu-se a esta proposta que os mesmos fossem, posteriormente, destinados para a direção da Entidade.

A proposta foi aceita na íntegra e, a partir de 1979, a direção do CEM esteve a cargo de seminaristas, não de dois, formalmente delegados para tal, mas efetivamente de uma equipe, pois todas as dicisões eram tomadas conjuntamente e toda a produção de material popular que ganhará impulso desta data em diante, terá como marca o mutirão! 


\section{Seminário e CEM}

No que se refere à relação entre os seminaristas e o CEM, podemos afirmar que a sensibilidade e solidariedade pastoral de uns cresce na proporção direta em que o Centro de Estudos se afirma como tal. Por outro lado, a gestação do CEM mergulha suas raízes não só no projeto mais amplo da Congregação, mas também nos próprios experimentos dos seminaristas e padres, os quais vão se dando conta da necessidade de entender mais profundamente as causas e implicações do fenômeno migratório. O ano de 1969, quando finalmente o CEM é criado, já encontra uma saudável familiaridade entre seus diretores e o ambiente do Seminário.

Mas os laços se estreitam ainda mais à medida que o centro vai ampliado suas atividades em duas direções: por um lado, criação de uma biblioteca especializada em migrações e promoção de cursos específicos no aprofundamento dessa temática; por outro, envolvimento progressivo nas atividades pastorais, sindicais e sóciopolíticas, sempre acompanhado de novas pesquisas no campo da mobilidade humana. Essa atividade cada vez mais febril dá origem à elaboração e publicação de subsídios que lhe serão correspondentes e que, por sua vez, geram novas formas de envolvimento na vida social e política da cidade. Em 1976, sob a coordenação de Pe. Levino Galli, realiza-se a primeira etapa de uma série de cursos de formação pastoral e migratória (CUPAM). Estes cursos destinavamse a sacerdotes, seminaristas, irmãs, ou seja, aos agentes de pastoral escalabrinianos. A partir de 1979, já estando os seminaristas à frente do CEM, estes cursos foram abertos a um público mais amplo, reunindo lideranças em nível nacional também preocupadas com a questão migratória.
Estas lideranças foram as que assumiram a tarefa de subsidiar a Campanha da Fraternidade de 1980 (CF/1980), sobre as migrações no Brasil. A partir de então, o CEM ganha um novo rosto, ou seja, passa a ser um interlocutor que dinamiza e articula a Pastoral Migratória em nível nacional, gestando o que viria a ser o atual Serviço Pastoral dos Migrantes (SPM). Vale ainda frisar que desse processo participaram ativamente várias religiosas escalabrinianas.

\section{CENÁRIO DOS ANOS 1970-1980}

\section{Contexto Eclesial}

Ainda que brevemente, e com o risco de certa superficialidade, vale a pena ampliar nosso olhar para o contexto eclesial nas décadas de 60 e 70. Quatro fatores no interior da Igreja iriam contribuir consideravelmente para a crescente atuação dos seminaristas e o fortalecimento do CEM. Em primeiro lugar, estávamos no auge da Teologia da Libertação. Esta reflexão teórica a partir da nova prática dos cristãos, em boa parte do continente latino-americano será decisiva para ampliar os horizontes dos estudantes de teologia e levá-los a posturas cada vez mais incisivas e radicais na chamada "opção pelos pobres". Os nomes de Gustavo Gutierrez, Juan Luis Segundo, Leonardo e Clodovis Boff, Jon Sobrino, - entre tantos outros tornam-se familiares não só nos corredores do Instituto Teológico de São Paulo (ITESP), mas também nos encontros de formação e aprofundamento das comunidades periféricas.

Em segundo lugar, multiplicavamse por todo o país, para não falar no continente, as experiências das
Comunidades Eclesiais de Base (CEB's). Inspiradas pela pedagogia da Ação Católica, centralizada no método Ver-Julgar-Agir, tais comunidades popularizavam uma nova leitura da Bíblia, na qual a Palavra de Deus, simultaneamente, traz luz sobre os problemas sociais do dia-a-dia e fornece pistas para solucioná-los de forma coletiva. O círculo hermenêutico - em que a práxis é interpelada pela teoria e esta, por sua vez, passa por um processo de reelaboração a partir da ação social - tornava-se o motor da vivência cristã. Não há como ignorar, por outro lado, o encontro entre este novo modo de entender a fé e a obra pedagógica de Paulo Freire. Os encontros inter-eclesiais de CEB's, que começam a se realizar neste período, convertem-se em grandes caixas de ressonância deste "novo jeito de ser Igreja".

Um terceiro elemento do cenário eclesial da época é a posição da Conferência Nacional dos Bispos do Brasil (CNBB) e, em particular, de alguns bispos proeminentes, entre os quais Dom Paulo Evaristo Arns. Um vôo de pássaro sobre os documentos eclesiais desse período, temperado pelos veementes pronunciamentos de certos prelados e pelos temas da Campanha da Fraternidade (CF), será suficiente para dar-nos conta de como o episcopado brasileiro dava suporte às práticas cristãs mais politizadas. Do ponto de vista que nos diz respeito mais diretamente, basta relembrar que a CF/ 1980 - com o lema Para onde vais? colocou em pauta a temática das migrações.

Por último, na segunda metade dos anos 70, começam a nascer as chamadas Pastorais Sociais. Podemos afirmar que elas representam serviços específicos a realidades e/ou categorias também específicas, em que a vida se encontra mais ameaçada. Alguns 
exemplos podem ilustrar essa afirmação: Pastoral da Terra, diante dos problemas relacionados à questão fundiária; Pastoral Operária, para acompanhar os desafios do mundo do trabalho; Pastoral do Menor, voltada para as crianças abandonadas; Pastoral Carcerária, como presença entre os detentos; Pastoral dos Migrantes, no acompanhamento dos fluxos e refluxos de grandes contingentes populacionais, e assim por diante.

\section{Contexto Sócio-histórico}

A ação dos seminaristas e do CEM ganha novo impulso no final dos anos 1970 e início dos anos 80. Também neste caso, determinados fatores, desta vez externos, contribuem decisivamente para isso. $\mathrm{O}$ primeiro deles, como não poderia deixar de ser, é a intensidade, diversidade e complexidade do fenômeno migratório. Não é este o espaço para discorrer sobre o tema das migrações,

\section{O sucesso de uma iniciativa de conjunto}

Um grupo de seminaristas do João XXIII, juntamente com catequistas das CEBs onde atuavam, a exemplo de Scalabrini - também conhecido como o Apóstolo da Catequese - logo parceberam o descompasso existente entre a caminhada da Igreja e o tradicional catecismo. Enquanto nos círculos bíblicos, na liturgia, na teologia acontecera uma "revolução", os manuais de catequese permaneciam os de perguntas e respostas.

Elaboraram, então, em 1976, um catecismo chamado "Libertação", destinado às comunidades das áreas onde atuavam. A cada ano o catecismo, em mutirão, era refeito, em duas versões, uma para catequistas e outra para alunos, integrando sempre o tema da Campanha da Fraternidade do ano. Era elaborado, datilografado e impresso em mimeógrafo manual no próprio Seminário. Rapidamente tornou-se conhecido e começaram a pipocar os pedidos.

Em 1979 aconteceu a $1^{a}$ reestruturação: Em vez de "Libertação", palavra pesada para as crianças, passou a chamar-se "Desperta". A partir de então, surgiu o Desperta 1, o Desperta 2 e o Desperta 3. Um mês de férias era destinado exclusivamente para a produção do Desperta, envolvendo uma considerável equipe: seminaristas, catequistas e jovens das comunidades que vinham trabalhar na montagem. $\mathrm{O}$ mimeógrafo manual funcionava de segunda a segunda, só parando quando as peças quebravam. E os pedidos não paravam de crescer, agora já em nível nacional. Eram pacotes e mais pacotes que seguiam pelo correio.

A alternativa foi pedir socorro à Diocese de Lins/SP, que passou a imprimir o Desperta. Mas a distância, à época, era um problema. $\mathrm{O}$ mesmo foi submetido às Edições Paulinas que imediatamente o aprovaram e passaram a imprimir e distribuir.

Por ser o primeiro na linha da Teologia da Libertação, o sucesso foi meteórico. O CEM não conta com registros de tiragem (à exceção dos anos 1980 a 1984, período em que foram impressos 165 mil exemplares dos Despertas 1 e 2, respectivamente) e os exemplares arquivados são os da $19^{\mathrm{a}}$ edição, mas foram muito mais. Quando o CEM recebia os direitos autorais, que representavam $0,8 \%$, a bolada era um considerável reforço de caixa, tanto assim, que numa das vezes, com o dinheiro recebido foi possível trocar o carro.

No decorrer dos anos de 1990, as Ed. Paulinas solicitaram que fosse feita uma nova atualização, os tempos, porém, já eram outros e o CEM não mais contava com a participação dos seminaristas do João XXIII.

que neste período transformava profundamente a sociedade brasileira. Basta assinalar, brevemente, a urbanização acelerada dos anos $60 \mathrm{e}$ 70, a corrida à fronteira agrícola, o aumento das migrações temporárias/ sazonais atrás das safras agrícolas, da construção civil e dos serviços em geral e, por fim, a entrada cada vez mais acentuada de imigrantes hispanoamericanos. O fluxo de brasileiros para o exterior mal havia começado. Evidente que o cenário dos deslocamentos humanos de massa provoca os estudantes de teologia, sobretudo na medida em que cresce sua ligação com o CEM e com os próprios migrantes. $\mathrm{O}$ estudo e o contato direto são duas fontes de inquietação e interpelação constantes.

O golpe militar em 1964 e seu acirramento com o AI5 em 1968, em segundo lugar, trouxe um tempo de silêncio, tempestade e turbulência que iria concretizar-se em perseguição, morte e desaparecimento de várias lideranças vinculadas à política, ao jornalismo, à Igreja, à organização sindical e estudantil. Os últimos anos da década de 60 e os primeiros da década seguinte, comandados pelo presidente Garrastazu Médici, justamente quando se fortalecia a experiência pastoral dos seminaristas do João XXIII, representaram o período mais sombrio do regime de exceção. Naquela época, lia-se com avidez os artigos censurados do Jornal da Arquidiocese, O São Paulo, que circulavam livremente pelos quartos do Seminário. A ação dos militares, aliás, espalhou temor e indignação em não poucos ambientes eclesiais, em parte porque a Igreja desempenhou o papel de um grande guarda-chuva, onde numerosas lideranças perseguidas pela polícia encontraram abrigo mais ou menos seguro, em parte porque alguns bispos, padres e irmãs se opuseram abertamente à ditadura 


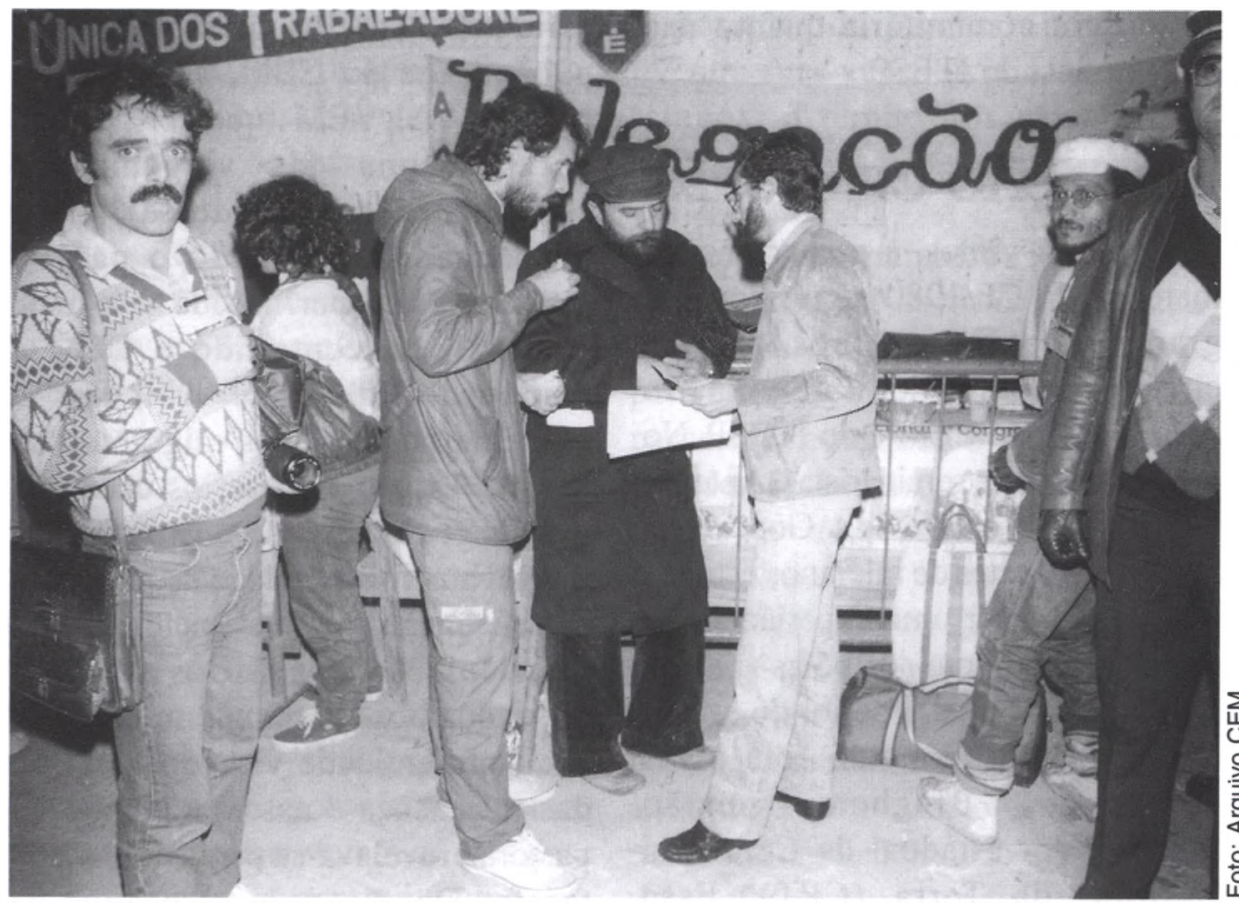

À esquerda, pe. Luís Bassegio, diretor do CEM e ao centro, Mercadante, Lula e Gilmar Carneiro. Salão Vera Cruz, São Bernardo do Campo, 1983 - Congresso da Fundação da CUT.

militar.

Outro fator de grande relevância, a partir de meados da década de 70 , foi a mobilização dos estudantes em São Paulo. Nas ruas e nas universidades, as questões sociais e políticas entravam em franca ebulição. Levantavam-se e cresciam de forma acelerada os primeiros protestos explícitos à política dos militares. Passeatas e discursos inflamados sucediam-se nas praças da cidade. "Abaixo a ditadura" era a palavra de ordem, intercalada com vaias, gritos, correrias e prisões. A cavalaria e infantaria do Coronel Erasmo Dias, de um lado, e a massa de estudantes, de outro, disputavam o espaço apertado entre os prédios da capital paulista. Entre essa massa, podia-se contar uma dezena de seminaristas do João XXIII, os mesmos integrados na pastoral da periferia e no trabalho do CEM. Aliás, das periferias viria somar-se à mobilização dos estudantes o movimento contra o custo de vida. Também chamado movimento das panelas vazias, reuniu milhares de dias de paralisação. E ainda, nos trabalhos de infra-estrutura da grande assembléia de trabalhadores que iria fundar a Central Única dos Trabalhadores (CUT), realizada no salão Vera Cruz, em São Bernardo do Campo, no ano de 1983, lá estavam novamente os seminaristas do João XXIII, sob a coordenação do Centro de Estudos. Como curiosidade, vale lembrar que os Estatutos de Fundação da CUT (6 mil exemplares), foram rodados no Seminário durante uma madrugada, da zero hora às seis da manhã, mutirão do qual participou, inclusive, o pe. Guglielmo Bellinato.

Por essas e outras, não seria exagero afirmar que o Partido dos Trabalhadores (PT), a CUT e a Pastoral Operária têm nas comunidades eclesiais um berço comum. Ali se formaram e dali saíram muitas das lideranças que nos dias atuais estão à frente da política brasileira. Bastaria verificar quantas vezes aqueles estudantes de teologia, a partir de 1982, quando alguns já eram padres, ajudaram no trabalho de "boca de urna" para a eleição dos candidatos do PT.

Uma conclusão se impõe: o trabalho pastoral nas comunidades da periferia, a participação nos movimentos estudantis, a contribuição à organização dos operários e o estudo da teologia constituíam dimensões distintas de uma mesma ação social. Como pano de fundo descortinava-se o horizonte da transformação social, política, econômica e cultural. Enquanto os instrumentos de análise vinculavam-se à matriz marxista, as motivações vitais provinham do clamor dos pobres e da experiência bíblica, especialmente na leitura dos Livros do Êxodo e dos profetas. Por isso que a vida social e política que fervia lá fora, nas ruas, fábricas e comunidades, repercutia com força e intensidade dentro do seminário, tanto 


\section{CEM: Editora e Gráfica?}

A equipe que assumiu o CEM a partir de 1979 dispunha de uma rede de contatos com as mais diversas entidades (hoje denominadas ONGs), ligadas à Igreja e aos Movimentos Sociais, bem como em nível Sindical e com pessoas ligadas às Universidades. Existia um grupo, composto por representantes das mais variadas entidades, que era responsável pela articulação entre as mesmas no que tange à produção e distribuição de material popular/ alternativo. Vale ressaltar que havia uma norma que orientava a produção, qual seja: não havia direito autoral sobre nada do que se produzisse para o povo. Tudo era feito para que chegasse às mãos do povo. Os desenhos, por exemplo, migravam de um boletim a outro, sobretudo nas bases onde os recursos eram por demais parcos. Algo de socialismo, a grande meta, chegou a ser balbuciado. Um caderno chamava-se "Capitalismo e Pessoa Humana", sequer sabia-se quem o produziu, e foi reproduzido às carradas.

Entretanto, o tema migrante constituía um vazio, mas que rapidamente foi preenchido. De 1980 a 1984, foram produzidos pelo CEM, que contava com a participação dos seminaristas do João XXIII e muitos outros parceiros, um total de 45 títulos e/ou publicações, que iam desde livros (resultado de Seminários/Simpósios), boletins, diapositivos, cartazes e, principalmente, livretos populares para serem utilizados nos grupos de base. Foram mais de 650 mil exemplares. Parte foi publicada através de editoras e/ou gráficas, mas muito material foi reproduzido em mimeógrafo.

Além do Desperta, o best seller, a Via Sacra do Migrante elaborada em 1980 atingiu 3 edições, num total de 83 mil exemplares, além dos $10 \mathrm{mil} \mathrm{em}$ versão inglesa, realizada pela CAFOD, Agência Católica de Cooperação Internacional da Inglaterra. Diariamente, pacotes e mais pacotes seguiam Brasil afora. na liturgia comunitária quanto nas salas de aula do ITESP.

\section{RELAÇÃO CEM/SPM}

Como já vimos, a preparação do material da $\mathrm{CF} / 1980$ significou um grande desafio a todos os que circulavam na órbita do Seminário João XXIII, do CEM e do ITESP. No mesmo ano, dois seminaristas, Antenor Dalla Vecchia e Alfredo J. Gonçalves, resolveram, antes de iniciar os estudos teológicos, fazer uma experiência no corte de cana junto aos bóias-frias na cidade de Dobrada, interior do estado de São Paulo, morando com o Pe. Domingos Bragheto, então coordenador estadual da Comissão Pastoral da Terra (CPT). Essa experiência, acompanhada e refletida pelos membros do CEM e por um grupo de seminaristas no João XXIII, abriu horizontes para o trabalho com os migrantes sazonais/temporários, que anualmente deixavam Minas Gerais e Bahia para a safra da cana na região de Ribeirão Preto, São Paulo. Anos mais tarde, surgiria um núcleo do trabalho pastoral entre origem e destino, que depois migraria para a cidade de Guariba, onde se localiza até hoje. Enquanto isso, prosseguia a presença dos demais estudantes de teologia nas comunidades, nos movimentos sociais e nas organizações sindicais. As salas do CEM funcionavam como uma espécie de oficina onde as experiências eram refletidas e aprofundadas e onde, por outro lado, construíam-se novos caminhos de ação pastoral.

Foi nessa oficina que o Serviço Pastoral dos Migrantes se forjou. A partir da CF/1980 os trabalhos do CEM se multiplicaram, o seu raio de influência se expandiu na medida em que a sensibilidade para com o fenômeno migratório crescia no interior da sociedade brasileira e nos diferentes meios pastorais. As publicações do CEM, sobretudo o boletim VAI-VEM (que foi gestado durante uma das viagens dos seminaristas ao Nordeste), eram despachadas para todo o país, e ganhavam um perfil cada vez mais pastoral, concentrando o CEM a responsabilidade de articular a nascente pastoral dos migrantes no Brasil. Assim, os desafios cada vez mais gritantes das migrações revelavam a necessidade de um ponto de referência, em nível nacional, para a articulação dos vários serviços prestados aos migrantes, e o CEM, enquanto entidade visando o estudo das migrações e assessoramento da pastoral, revelava-se pequeno para tal tarefa. Depois de quatro anos de gestação e de alguns encontros e assembléias prévias, nasce o SPM numa assembléia de fundação realizada em Brasília/DF, no ano de 1985. Ligou-se imediatamente à chamada linha 6 da CNBB, posteriormente organizada como Setor Pastoral Social, espaço que passou a integrar o conjunto das Pastorais Sociais da Igreja no Brasil. Somente em 2004, com a nova estruturação da Conferência Episcopal Brasileira, viria a formar-se o Setor de Mobilidade Humana, responsável pelos diversos serviços nesse campo.

Por um breve período, a organização do SPM abrigou-se nas dependências do João XXIII, ao lado do CEM, depois passou para uma sede própria. Com o correr dos anos, implícita ou explicitamente, CEM e SPM efetuam uma certa divisão de trabalho. Enquanto o primeiro voltase mais para o estudo e a pesquisa, o segundo dedica-se à atividade pastoral. Em fevereiro de 1989, sob a responsabilidade do Pe. Alfredo J. Gonçalves como diretor, o CEM transfere-se para o complexo da Igreja Nossa Senhora da Paz, onde se 


\section{Um fato que só a memória preserva}

Foi no ano de 1982, mês de setembro, o mais adequado, pois o destino era Rondônia. A estrada que nos conduziria até lá - partíamos de São Paulo -, além-Cuiabá era de puro chão. Só no período pós-chuvas seria possível uma programação com data de saída e chegada. Com a mochila nas costas e nela, roupa pouca, caneta e um caderno, além da máquina fotográfica, Adair e eu partíamos para a ausência de um mês.

Uma semana depois, lá estávamos tragando o pó das estradas e a fumaça das queimadas. Saltitando de núcleo em núcleo, com a máquina ele tudo registrava e, no papel, com a caneta, eu o fazia. Mas parte de uma conversa só nos bastidores permaneceu guardada. Foi em Ji-Paraná, comigo e o morenobaixinho D. José Martins da Silva, à época bispo daquela enorme Prelazia.

A incursão por Rondônia inscrevia-se na tradição do Seminário João XXIII e do CEM de perseguir os principais fluxos migratórios. Rondônia, é verdade, já ia tarde, pois a grande onda migratória teve início com o primeiro assentamento em 1969, ganhando expressivo volume a partir de meados da década de 1970.

O objetivo da viagem foi traçado coletivamente: fazer um levantamento da realidade migratória; elaborar uma matéria especial para o Boletim Vai Vem ("Rondônia para os Migrantes ou os Migrantes para Rondônia"? - ano 2, $\mathrm{n}^{\circ} 7$, dezembro/82, pp. 4-14) e, nos bastidores, sondar caminhos para uma futura (e urgente) presença escalabriniana naquela fronteira. Nos sonhos da equipe, além de Rondônia, uma frente junto aos migrantes temporários no interior paulista e uma no Nordeste constituíam metas de curto prazo.

$\mathrm{Na}$ véspera da partida, um pulo até a sede provincial para um até logo ao pe. Giancarlo Rizzinelli, então provincial. O "até logo" não se estendeu por mais de dez minutos, tempo suficiente para o Giancarlo - que conhecia o plantel que dirigia - fazer, quando eu já virava as costas, a recomendação explícita, e sublinhada pelo tom da voz, para que não fosse semeada a expectativa de que os escalabrinianos assumiriam uma missão em Rondônia. Nada foi retrucado; aquilo soou apenas como reforço às intenções da viagem.

Na sala abafada de D. José Martins, após uma entrevista formal, antes da despedida, ainda de frente, foi-lhe feita a seguinte recomendação, com um breve preâmbulo: "Para todos os efeitos, pelo que será solicitado agora, você nunca nos viu e ninguém esteve aqui em Ji-Paraná por esses dias. E você faça o seguinte: escreva ao Provincial uma carta por semana, insistindo que lugar de escalabrinianos é aqui, pois teremos uma assembléia em novembro e queremos colocar Rondônia na pauta". Ele sorriu e prometeu que o faria. Seguiu-se a despedida e prosseguimos viagem.
Durante a XI Assembléia, realizada entre os dias 23 e 25/ 11/1982), exatamente no salão do CEM, quando o assunto em pauta tratava do fechamento e abertura de posições, num determinado momento, pe. Giancarlo levantou-se da cadeira e, com seu jeito típico, tirando aqueles óculos de hastes grandes antes de falar, dirigiu-se à platéia nos seguintes termos: - Tratase de um comunicado apenas, o bispo de Ji-Paraná, através de carta, está solicitando uma presença nossa em Rondônia! Giancarlo falara tratar-se de um comunicado apenas, pois a orientação da Assembléia era para se indicar perspectivas de novas frentes de atuação, mas não definição concreta de lugares, isso o faria a Direção Provincial, posteriormente. Inteligentemente, Giancarlo guardou o conteúdo da carta. Esta, escrita por D. José aos 06/10/1982, rezava: "Estou me dirigindo ao Sr. para um apelo concreto (...) uma presença em nossa Prelazia (...) inegavelmente, hoje, lugar de maior concentração de migrantes. (...) Para o ano que vem já teria lugar definido para lhes entregar ou até agora mesmo. (...) Na expectativa de um pronunciamento favorável (...)".

Mal acabara de pronunciar a frase, vários braços já se haviam erguido solicitando a palavra. Um após outro, todos os que falaram, defenderam, inicialmente, a pertinência da solicitação do bispo e, posteriormente, que a assembléia deveria deliberar sobre o assunto. De fato, a mesa só pôde dar prosseguimento à pauta após colocar o assunto em votação.

As articulações que exigiam maior fôlego já haviam sido realizadas previamente e, na hora, um rápido lobby feito em mutirão no transcorrer dos burburinhos, garantiu a vitória favoravelmente ao pedido do bispo. Mas o desafio de uma presença em Rondônia não estava totalmente vencido. "Quem se dispõe a ir, indagou Giancarlo?" Para a instituição, a questão, no momento, colocava-se nos seguintes termos: tirar a calça de um para vestir a outro. Um intervalo, porém, foi mais que suficiente para dar viabilidade à decisão. Enquanto uns tomavam tranqüilamente seu café, outros, numa roda que se formou rapidamente, discretamente afastada do centro das atenções - a mesa do café - encontraram a solução. No CEM, para a instituição, atuavam dois padres recentemente destinados para lá. Entretanto, ali atuava uma equipe e, por ser uma equipe, a saída de uma pessoa não representava despir a um para vestir a outro. O Luiz Bassegio cursava pós-graduação na PUC, não tive dúvida, ofereci-me para o pontapé inicial e o consenso do grupo foi imediato. Por um lapso, meu nome não consta entre os participantes da XI Assembléia, mas o que os documentos oficiais não registram, a memória preserva.

E assim, no dia 29 de fevereiro de 1984, sob uma chuva torrencial, os escalabrinianos bateram novamente às portas da sede diocesana de Ji-Paraná, desta vez para armar a tenda. 
encontra atualmente.

\section{O PASSADO E 0 FUTURO DA PASTORAL DOS MIGRANTES}

Os seminaristas do João XXIII, nas últimas quatro décadas, estiveram à frente de projetos e atividades pioneiras que originaram a pastoral dos migrantes no Brasil e acompanharam de perto o pensamento e a ação das principais iniciativas políticas populares no país. Foram estas iniciativas que, de um jeito ou de outro, forjaram nesse período aquilo que se tornou atualmente a pastoral dos migrantes e, em âmbito maior, a concepção de um "projeto popular para o país". A eleição do presidente Lula canalizou os esforços concentrados dessa ampla mobilização, a qual tem raízes na prática eclesial, no sindicalismo combativo, na organização estudantil, nos movimentos e pastorais sociais, além, é claro, de vários outros importantes segmentos da sociedade.

Não é novidade para ninguém o fato de que o Concílio Ecumênico Vaticano II representou um movimento centrífugo da Igreja em direção ao mundo moderno. Nisto está o significado da expressão do Papa João XXIII ao abrir os trabalhos do Concílio: "É preciso abrir as janelas do Vaticano para a entrada de novos ares", ou no que dizia, muito tempo antes, João Batista Scalabrini: "O mundo caminha e nós não podemos ficar para trás". A abertura às descobertas da ciência, ao diálogo com as demais Igrejas cristãs e denominações religiosas, às “alegrias e esperanças, tristezas e angústias dos homens de hoje" foi, sem dúvida, o grande mérito daquele evento. As repercussões e desdobramentos de tal abertura, especialmente nos países da
América Latina e no Brasil, encontrase impressa nos documentos das Igrejas Locais destes países e na tomada de posição de muitos bispos a favor dos pobres, bem como na prática sócio-política de uma massa crescente de cristãos e nos avanços da reflexão teológica. Ainda no caso da América Latina, a "violência institucionalizada", a injustiça, a corrupção e os regimes militares ajudaram a tornar mais radical e incisiva a opção pelos pobres.

Com o pontificado de João Paulo II e mais ainda agora, com Bento XVI, alguns estudiosos chamam a atenção para um movimento centrípeto, em que a Igreja se concentra predominantemente nas questões de ordem moral e religiosa e na defesa intransigente da doutrina. Os problemas políticos e sociais tendem a ser ignorados, ou ficam em segundo plano. Os temas ligados à liturgia, ao celibato religioso, à catequese e à imagem externa da Igreja, por um lado, e, por outro, os debates em torno do aborto, do uso de preservativos, da vida familiar ocupam a maior parte da pauta eclesiástica. Essa espécie de involução na pastoral, como a denominam outros analistas, vem acompanhada de um crescente centralismo das decisões e autoritarismo nas práticas. A colegialidade como marca registrada do Concílio Vaticano II - implícita na expressão Igreja Povo de Deus - dá lugar a um peso bem maior na figura do bispo e da Cúria Romana. No que se refere ao Brasil, confirmam isso a recente aprovação dos novos estatutos e do regimento interno da CNBB, como também a última eleição de sua Direção. O presidencialismo ganha prioridade sobre a assembléia colegiada dos bispos. Isto para não falar dos leigos e leigas, cujas funções tendem a restringir-se cada vez mais.

Diante de semelhante quadro, como fica a nova formação dos seminaristas?
Haverá ainda abertura para as questões sociais e políticas? Existe um processo de internacionalização do projeto formativo, visando também uma presença da Igreja no mundo das migrações, em uma sociedade cada vez mais globalizada. Qual a incidência dessa história recente da pastoral dos migrantes sobre essa nova geração de seminaristas? Vimos acima que, nos anos 70, o Seminário João XXIII era uma espécie de caixa de ressonância dos problemas que afligiam a população pobre, notadamente os migrantes. Aliás, essa sensibilidade não era prerrogativa dos seminaristas. Toda a orientação e o espírito do Concílio Vaticano II, vale repetir, voltavam-se para as aflições humanas, o que se encontra expresso de forma magistral na frase de abertura da Constituição Pastoral Gaudium et Spes, sobre a Igreja no Mundo de Hoje: "As alegrias e as esperanças, as tristezas e as angústias dos homens de hoje, sobretudo dos pobres e de todos aqueles que sofrem, são também as alegrias e as esperanças, as tristezas e as angústias dos discípulos de Jesus Cristo; e não há realidade alguma verdadeiramente humana que não encontre eco no seu coração" (G.S.§1). Era também a postura profética da CNBB, sobretudo em algumas de suas personagens históricas.

Hoje, os tempos são outros, é verdade, mas os desafios continuam. Cabe, pois, deixar em aberto uma pergunta como ponto final: continuará sendo o Seminário João XXIII, junto com o CEM, o SPM e o ITESP, uma oficina de uma ação pastoral voltada, simultaneamente, para os apelos de Deus e os desafios da história na pessoa dos migrantes?

* Pe. Alfredo J. Gonçalves integra a Coordenação Nacional e a Equipe de Assessoria da IV Semana Social Brasileira.

** Dirceu Cutti - Centro de Estudos Migratórios. 